\title{
Evaluation of Training to Improve Ability of Lecturers' Learning Design
}

\author{
1st Tina Rosa \\ Magister Administration Bussiness \\ Respati Indonesia University \\ Jakarta, Indonesia \\ tinakynan@yahoo.co.id
}

\author{
2nd Yusdi Anra \\ Anthropology Department \\ Jambi University \\ Jambi, Indonesia \\ yusdiandra@yahoo.com
}

\begin{abstract}
This evaluative research aimed to get information on the implementation of the Training Program Instructional Skills Techniques conducted by Regional Coordinator Private Education III Jakarta. Educational systems in Indonesia are standardization system, in which the lecturer must evolve and improve knowledge and should be an effective facilitator of learning for students. Lecturers are required to manage the learning so that knowledge is discussed easily understood by students. In the learning process takes a lecturer who is able to manage the class well into a learning center where students and faculty provide equal opportunities to each student to develop their students. To improve the ability of lecturers required continuous training where each training program should be evaluated to improve the quality of the learning process. Data sources were obtained through in-depth interviews and supported with documents analysis of training from years 2012-2014. Interview were carried out to the following respondents (1) the committee from Coordinator III, (2) alumni from colleges that have accreditation A, B and $C$, (3) as well as the respective people to whom the alumni responsible. The methods use was combien, the evaluation program Logic of W.K. Kellogg consisting of; (1) research (input), (2) activity, (3) output and (4) outcome, and with the evaluation of the four levels of Kirkpatrick: (1) reaction, (2) learning, (3) behavior, and (4) result. The evaluation model that used for skills training instructional techniques consists of (1) evaluation input, (2) evaluation activity that concern of the Implementation Plan, (3) evaluation of Learning process, and (4) Result evaluation that focus at outcome and behavior. The results showed that; 1) Input Evaluation, college with accreditation A, B has scored 3, had a significantly better outcome, college with accreditation $C$ gets the value 2, significantly sufficient results; 2) Evaluation Implementation Planning, college with accreditation $A, B$ has scored 3 had a significantly better outcome, college with accreditation C has scorde 2, (good results) significantly enough results; 3) Evaluation of Learning Process, college with accreditation $A, B$ and $C$ has scored 3, (good results); 4) Evaluation, college which accreditation $A, B$ and $C$ has score 3, (good results). It's a concluded that in order to improve the effectiveness of skills training instructional techniques need to evaluation that improve some aspects implementation of the particular amount 4 times a year, number of participants 160 people (1.3\%), and must evaluate the results of learning process to monitor developments in the private colleges.
\end{abstract}

Keywords- Training Evaluatian, Improve Ability; Lecturer's Learning Design

\section{INTRODUCTION}

Indonesia educational systems standardization, that lecturer must evolve and improve knowledge and should be an effective facilitator of learning. Lecturers are required to manage the learning, knowledge is discussed easily understood. In learning process lecturer must able manage classes well and become faculty provide to equal opportunities and develop their students. To improve the ability, lecturers required continuous training and each training should be evaluated to improve the quality.

The purpose of evaluation to obtain information based on the data collected, processed so that the conclusions of the evaluation can be delivered to the stock holders, whether the program is worthy forwarded, stopped or repaired so that the program becomes more effective. The Coordinator (Law No. 20 of 2003 on Article 66) has the obligation to perform control and coaching at the college, with no prejudice to the autonomy at college. Under coordinator Region III, there are 345 private colleges consisting of (1) 51 universities, (2) 11 Institutes, (3) 145 high schools, (4) 132 colleges and (4) 8 polytechnics. And in 1551 the number of courses, of which $57 \%$ is already accredited, and $43 \%$ have not been accredited. Under Coordinator III number of lecturers as many as 19.240 people consisting of; (1) 18294 the foundation lecturers, public lecturers 962 (5\%).

In the region of Coordinator III, professors who have levels of academic S3 amounted to 7119 (37\%) of people, professors who have levels of academic S2 amounted to 9,812 people, as well as the lecturers still have levels of academic S1 totaled 2,309 people, to functional new professors amounted to 385 ( $2 \%$ ) of people, an assistant professor with the functional position of experts amounted to 3,848 (20\%) of people, and lecturers who do not have a functional positions (faculty) accounted for 8466 (44\%) of people. Lecturers who have passed professional certification amounted to 3,394 people. 
The training program improvement instructional techniques held by Coordinator III, is a program that is comprehensive, systematic and has a foundation of clear regulations in terms of legislation and government policy, which include human resources must have certain requirements, specific facilities, processes sustainable and products that are real and sustainable, and has been held for 19 years, with training alumni reached 800 , involving 345 private colleges, for organizing the training need time and great expense, it is necessary to evaluate, as long as this has not been done training evaluation, once completed.

Task lecturer are (Mulyasa 2013); (a) lack learning strategies, (b) lack in managing classroom, (c) low ability to perform and take advantage classroom action research, (d) low achievement motivation, (e) lack of discipline, (f) lack of commitment, and $(\mathrm{g})$ lack time management skills.

Evaluation of the implementation of training to improve instructional techniques ability design, has been organizer and reported in the form of a report of activities each year, but have never take evaluation after the participants back on duty.

There are three concepts in-depth evaluation that self-reflection, identifying needs, opportunities, strengths and weaknesses analysis of the object to be evaluated as well as to answer the needs that underlie the formulation of a program, as well as in-depth explanation of the evaluation. Focus evaluation on reliability, effective, efficient, safe, easy to use and reliable. Evaluation is a judgment on the value or the implications of the result of the measurement, and evaluation is the process of determining the extent to which educational goals achieved (Tracy, 2013)

Evaluation logic used as a planning tool for managing, documenting activities, redesigning the organization and problem solving. The application of logic models as a planning tool to use appropriate communication in accordance with program objectives, components, sequence of activities and achievements of the program (W.K. Kellog, 1998, Owen 1993)

Evaluation is based selection logic model evaluation of W.K. Kellog, and Four Level of Kirk Patric, the reason to combine components ranging evaluation program inputs (input) which is an evaluation process input in the form of program policy, planning evaluation activities (activities) participants in the learning process, evaluation of the learning process (learning), output evaluation of learning outcomes by seeing an increase in the learning process and changes in participant behavior (outcomes, behavior), at which time the trainee ability teach design gain an increased ability for the learning process in accordance with the standards followed to change behavior inherent in evaluation.

So through the study wanted to know the effectiveness of training conducted by Coodrinator III, as well as to enhance the professionalism of the human resources of private colleges that are under coordinator Coodinator Region III.

\section{METHOD}

This study is based evaluative Coordinator III cases in Jakarta, by combining evaluation methods that include program evaluation program Logic of W.K. Kellogg consisting of; (1) research (input), (2) activity, (3) output and (4) outcome, with the evaluation of the four levels of Kirkpatrick: (1) reaction, (2) learning, (3) behavior, and (4) result, so that the evaluation model used for skills training instructional techniques consists of (1) evaluation Feedback, (2) evaluation of the Implementation Plan, (3) evaluation of Learning process, and (4) evaluation.

The method used in this research is qualitative descriptive evaluative approach from the corner of a review of case studies. Using evaluation model is a model of program evaluation Logic of W.K. Kellogg, and evaluation of training programs of Kirkpatrick who was the use mode which includes an evaluation input, the evaluation of activity planning, evaluation of the learning process, and evaluation of training results based on the increase in the deployment process ability teach design, as well as behavioral changes are attached, to see the effectiveness of education and training skills training instructional techniques held by Coordinator Region III Jakarta with the study design is presented in.

The research data were analyzed using descriptive qualitative analysis techniques. The analysis is used to view the results of the evaluation of training programs Coordinator Region III Jakarta presented in the form of an explanation based on interviews and through observation documentation and see firsthand the evidence of planning units of learning events held by the alumni of vocational training instructional techniques for further interpretation data. The stages of data analysis include: 1) data reduction, 2) Presentation of data, and 3) inference / verification.

Criteria of evaluation research ability teach design based training program; (1) evaluation of the input that is the formulation, strategic planning, written policies, objectives achievement activities, standardization of processes, laws and regulations that support the implementation of training ability teach design; (2) evaluation of the planning activities that are planned modules and facilities that meet the standardization of training; (3) evaluation of the learning process, namely the achievement of infrastructure is standardized and professional speaker; (4) evaluation of the result which is to achieve standardization in the manufacturing units of learning events and classroom management.

Data from 2012 - 2016, entry the classrom training, interview all the participant, the student, and using mix method to make a conclusion. 
Lecturer Learning Design

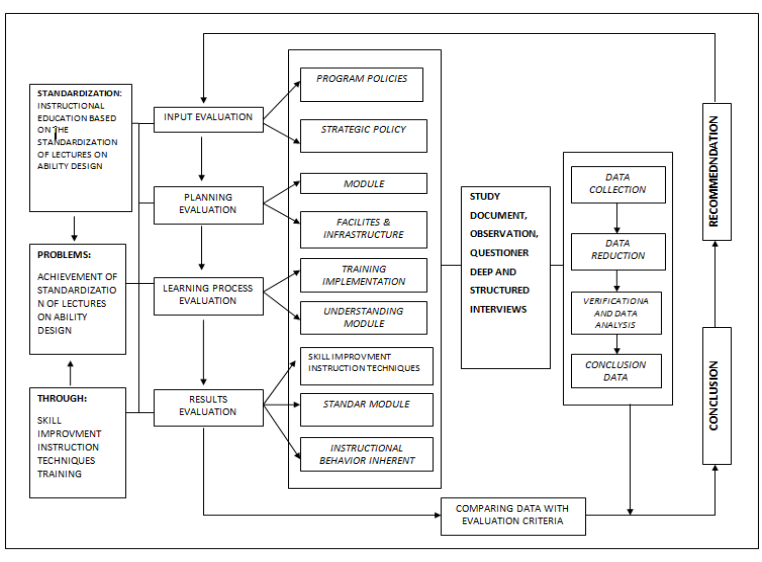

\section{RESULTS}

The results of the evaluation at private colleges based on accreditation, based on the input component, planning activities, the learning process and the evaluation of results, illustrated by the following table:

Table 1: Evaluation Result

\begin{tabular}{|c|c|c|c|c|c|c|}
\hline \multirow{2}{*}{ No } & \multirow{2}{*}{ Accreditation } & \multicolumn{5}{|c|}{ Componen } \\
\hline & & Input & Planning & Learr & gProcess & Outcome \\
\hline 1 & $A$ & \begin{tabular}{l|l}
3 & Good
\end{tabular} & \begin{tabular}{l|l}
3 & Good
\end{tabular} & 3 & Good & 3 Good \\
\hline 2 & $B$ & 3 Good & 3 Good & 3 & Good & 3 Good \\
\hline 3 & $C$ & 2 Enough & 2 Enough & 3 & Good & 3 Good \\
\hline
\end{tabular}

Evalution results say that : (1) Lecturer from private university from $\mathrm{A}$ and $\mathrm{B}$ accreditation are good; (2) C accreditation for input and planning enough. But the lecturers told that architecture, chemistry, nurse, and other practicum program, which for the training program it must evaluatation again because it's can't be compatible.

\section{DISCUSSION}

The training program skills upgrading instructional techniques is very important to enhance the professional capabilities of educators as teachers are especially with the development of curriculumbased framework of national qualifications Indonesia where education is a framework spacing qualification of human resources in Indonesia, which is put, equalizes, and integrating the education sector by sector training and work experience in a recognition scheme workability adapted to the structure in the industrialized world.

Achievement of the most out of training can't be separated from the ideal number of participants as well as the timing of effective and efficient so that the material provided can be optimally absorbed by the participants.
The number of participants should be limited, by providing academic requirements that must be fulfilled by the college and the professors who follow the training to improve skills instructional techniques.

Trainees in the classification, especially, for the young professor who has not had a functional level, up to a maximum function lecturers and lectors level.

The process of training, development and learning for skills enhancement training instructional techniques appropriate for participants educators, will improve the quality of education in general in Indonesia, so as to achieve standardization of educators qualified in the field of teaching professionals.

For the evaluation of the input (input), evaluation is how a policy and program formulation skills training to improve instructional techniques is created.

Strategic planning and clear policies for the training program to achieve standardization of professionalism lecturers, is closely related to the relevance of short-term goals and long-term Coordinator III and understanding of legislation and policy making success of a training program specifically training skills upgrading instructional techniques, can achieve maximum results.

The results of the evaluation of the input is the understanding that the implementation of the training is efficient and effective should be planned to the maximum, ranging from legislation to the trainees who qualify, where such requirements are factors monitoring of Coordinator III through reporting that must be met by the college private.

Planning evaluation activities, where evaluation is done based on the knowledge of participants in the planning process and resource activities generating module having a maximum competence in their field to face many obstacles and provide solutions to the possibility that the obstacles that arise.

Evaluation of the learning process is very supportive to see the extent of absorption of the material provided. It is not only concerned about the infrastructure, but also on how the flow of information needed by the participants, how the services received by participants.

To find out the results of the implementation of a training evaluation training results where evaluation to see whether there is improvement of the learning process in accordance with the standard framework of national qualifications Indonesia as well as behavioral changes inherent in private (behavior) lecturers who have training skills building training instructional techniques (character).

Evaluation of the results has not been implemented by Coordinator III associated with limited human resources and lack of financial resources that are not on the checklist implementation of the budget. 


\section{CONCLUSION}

Recruitment standards must be open and can understood by the trainee instructional skill enhancement techniques, but one written rules about reporting at minister of education web should reach $98 \%$ already held by private colleges. Training for other standards such as (1) a young lecturer, (2) maximum functional level lector, (3) has not been trained the skills of instructional techniques, understood by the trainee, employer participants and institutions where trainees shelter.

In planning evaluation activities, was found to point planning training materials, participants stated that the modules according to the needs of the profession lecturer with subjects taught.

In the evaluation of the learning process, based on data gathered from the implementation instructional skills enhancement techniques through; (1) book reports on activities, (2) interviews with participants, concluded based on aspects of good training materials, can be implemented in the workplace. But for vocational courses that specification, such as the subject (1) architecture (2) flight management, and (3) letigation, which requires a lot of practice, they must be adapted and developed further.

Based on the evaluation of (1) the result of attitudes (outcome) and (2) the inherent behavioral changes that persist (behavior) on the alumni participants instructional skills enhancement techniques, there is a change in attitudes and behaviors that persist, particularly in the learning process.

The organizers implementation skills upgrading instructional techniques, in which case Coordinator III did not do an evaluation after the participants return to work into college, due to lack of funds checklist implementation of the budget (DIPA) to evaluate the results of training organized by Coordinator III ,

\section{BIBLIOGRAPHY}

Aiken, Lewis R. (1996). Rating Scales And Checklis: Evaluating Behavior, Personality And Attitude. New York: John Wiley \& Sons Inc.

Andriyansah, Fatia Fatimah dan Paryanta (2014). Become a Skilled and Professional Tutor. Yogyakarta: Graha Ilmu.

Arifin, Zainal (2009). Evaluation of Learning. Bandung: Rosda Karya.

Arikunto, Suharsimi (2013). The Basics of Educational Evaluation. Jakarta: Bumi Aksara.

Arikunto, Suharsimi dan Cepi Safrudin Abdul Jabar (2014). Evaluation of Educational Programs: Pratical Theoretical Guidelines For Students and Educatioan Pracitioners. Jakarta: Bumi Aksar.

Arikunto, Suharsimi (2013). Management Research. Jakarta: Rineka Cipta.

Arikunto, Suharsimi dan Suhardjono dan Supardi (2012). Classroom Action Research. Jakarta: Bumi Aksara.
Arwildayanto (2013). Hoger onderwijs Human Resource Management. Bandung: Alfabeta.

Atwodiwiro, Soebagio (2015). Mangement Training. Jakarta: Ardadizya Jaya.

Creswell, John W (2002). Research Design: Qualitative, Quantitative and Mix Methods Approaches. California: Sage Publication Inc.

Daryanto . (2013). School Management Administration. Jakarta: Rineka Cipta.

Daryanto dan Bintoro (2014). Management Training. Yogyakarta. Gava Media.

Daryanto (2013). Menyusun Modul: Teaching Materials For Teacher Preparation In Teaching. Yogyakarta. Gava Media.

Djaali dan Pudji Mulyono (2008). Measurements In The Field Of Education. Jakarta: Grasindo.

Emzir (2012). Qualitative Research Methodology: Analysis Data. Jakarta: Raja Grafindo Persada.

Guba, Egon G. dan Yvonna S Lincoln (1981). Effective Evaluation: Improving The Usefulness Of Evaluation Results Through Responsive and Naturalistic Approaches. California: Jossey Bass Inc. Publisher.

Gintings, Abdorrakhman (2011). Practical Essence: Education Management and Training. Bandung: Humaniora.

Indrawan Rully, Yaniawati Poppy (2014). Research Methodology: Quantitative, Qualitative and Mix for Management, Development and Education. Bandung: Refika Aditama.

Kellogg, W.K. (1998) Creating Program Logic Models. New York: Foundation Evaluation Handbook.

Kirkpatrick, Donal L dan James D. Kirpatrick (2006). Evaluating Training Programs. San Fransisco: Berrett-Koehler Publisher, Inc.

McEwan, Elaine K (2014). 10 Characters Which Highly Effective Teachers Must Have: How to Recruit, Train and Lead Successful Teachers. Jakarta: PT. Indeks, Permata Puri Media.

Mardapi, Djemari (2012). Measurement of Educational Assessment and Evaluation. Yogyakarta: Nuha Litera.

Mulyasa (2013). Competency Standards and Teacher Certification. Bandung: PT. Rosdakarya.

Musfah Jejen (2012). Teacher Competency Improvement: Through Training and Learning Resources Theory and Practice. Jakarta: Kencana Prenada Media Group.

Patton, Michael Quinn (1990). Qualitative Evaluation And Research Methods: Second Editon. California: Sage Publications.

Pidarta, Made (2011). Indonesia Education Management. Jakarta: Rineka Cipta.

Purwanto, dan Atwi Suparman (1999). Evaluation of Training Program. Jakarta: STIE LAN Press.

Purwanto (2010). Social Research and Education Instruments: Development and Utilization. Yogyakarta: Pustaka Pelajar.

Rae Lislie (2000), Effective Planning: In Training And Development. London: British Library.

Stufflebeam Daniel L., Anthony J. Shinkfield (2007). Evaluation: Theory, Models, \& Applications. San Francisco: Jossey-Bass.

Sudijono, Anas (2013). Intriductory Evaluation of Educatioan. Jakarta: Rajagrafindo Persada.

Sugiyono (2014). Research Method of Management: Quantitatif Approach, Qualitatif, Mixed 
Methods, Action Research, Evaluation Research. Bandung: Alfabeta.

Sukardi (2012). Education Evaluation: Principle and Operations. Jakarta: Bumi Aksara.

Supardi (2014). Teachers Performance. Jakarta: Rajawali Pers.

Tayibnapis, Yusuf Farida (2008). Program and Instrument Evaluation: For Education and Training Program. Jakarta: Rineka Cipta.

Tilaar H.A.R. (2012), Standardization of National Education, A Critical Review. Jakarta: Rineka Cipta.

Team Coordinator III (2014). Workshop Guied, Applied Approach, Coordinator III DKI Jakarta. Jakarta: Coordinator III.

Government Regulation:

Government Regulation No. 87, 2013, about The Profesional Education Program of Pre-Service Teacher

Regulation of National Education Minister No. 49, 2014, about The National Education Standard

Government Regulation No. 19 , 2005 about The National Education Standard 